\title{
Impact of capillary rise and recirculation on simulated crop yields
}

\author{
Joop Kroes ${ }^{1}$, Iwan Supit ${ }^{1,2}$, Jos van Dam ${ }^{3}$, Paul van Walsum ${ }^{1}$, and Martin Mulder ${ }^{1}$ \\ ${ }^{1}$ Wageningen University \& Research - Wageningen Environmental Research, Wageningen, the Netherlands \\ ${ }^{2}$ Wageningen University \& Research - Chair Water Systems and Global Change, Wageningen, the Netherlands \\ ${ }^{3}$ Wageningen University \& Research - Chair Soil Physics and Land Management, Wageningen, the Netherlands
}

Correspondence: Joop G. Kroes (joop.kroes@wur.nl)

Received: 13 April 2017 - Discussion started: 20 April 2017

Revised: 17 April 2018 - Accepted: 22 April 2018 - Published: 17 May 2018

\begin{abstract}
Upward soil water flow is a vital supply of water to crops. The purpose of this study is to determine if upward flow and recirculated percolation water can be quantified separately, and to determine the contribution of capillary rise and recirculated water to crop yield and groundwater recharge. Therefore, we performed impact analyses of various soil water flow regimes on grass, maize and potato yields in the Dutch delta. Flow regimes are characterized by soil composition and groundwater depth and derived from a national soil database. The intermittent occurrence of upward flow and its influence on crop growth are simulated with the combined SWAP-WOFOST model using various boundary conditions. Case studies and model experiments are used to illustrate the impact of upward flow on yield and crop growth. This impact is clearly present in situations with relatively shallow groundwater levels ( $85 \%$ of the Netherlands), where capillary rise is a well-known source of upward flow; but also in free-draining situations the impact of upward flow is considerable. In the latter case recirculated percolation water is the flow source. To make this impact explicit we implemented a synthetic modelling option that stops upward flow from reaching the root zone, without inhibiting percolation. Such a hypothetically moisture-stressed situation compared to a natural one in the presence of shallow groundwater shows mean yield reductions for grassland, maize and potatoes of respectively 26,3 and $14 \%$ or respectively about $3.7,0.3$ and $1.5 \mathrm{t}$ dry matter per hectare. About half of the withheld water behind these yield effects comes from recirculated percolation water as occurs in free-drainage conditions and the other half comes from increased upward capillary rise. Soil water and crop growth modelling should consider both capillary rise from groundwater and recirculation of percolation water as this improves the accuracy of yield simulations. This also im-
\end{abstract}

proves the accuracy of the simulated groundwater recharge: neglecting these processes causes overestimates of $17 \%$ for grassland and $46 \%$ for potatoes, or 63 and $34 \mathrm{~mm} \mathrm{yr}^{-1}$, respectively.

\section{Introduction}

Crop growth strongly depends on soil moisture conditions. Climate variables determine these conditions through rain that penetrates directly into the root zone or comes available via lateral flow. The moisture distribution in the soil strongly depends on soil physical properties that determine vertical flow. Upward soil water flow becomes an especially vital supply term of a crop when the soil water potential gradient induced by the root extraction manages to bridge the distance to the capillary fringe, inducing increased capillary rise. In this paper we follow the definition of capillary rise given by the Soil Science Society of America (SSSA, 2008), as the "phenomenon that occurs when small pores which reduce the water potential are in contact with free water". This implies that capillary rise as a source for upward flow to crop roots requires the presence of a groundwater table. In conditions without a groundwater table there may also be a contribution of upward flow to crop roots through the process of recirculation. Recirculation is a known process discussed already by Feodoroff (1969) but has never been quantified. We quantified recirculation separately from capillary rise using model experiments.

The contribution of (intermittent) upward flow to the total water budget can be significant. For example Kowalik (2006) mentions that during the grass growing season, in soils with the groundwater close to the soil surface (Aquepts), the cap- 
illary rise induced by root extraction varies between 60 and $150 \mathrm{~mm} \mathrm{yr}^{-}$. Babajimopoulos et al. (2007) found that under the specific field conditions about $3.6 \mathrm{~mm} \mathrm{~d}^{-1}$ of the water in the root zone originated from the shallow water table, which amounts to about $18 \%$ of the water transpired by a maize crop. Fan et al. (2013) analysed the groundwater depth globally and concluded that shallow groundwater influences 22 to $32 \%$ of global land area, and that 7 to $17 \%$ of this area has a water table within or close to plant rooting depths, suggesting a widespread influence of groundwater on crops. This is especially the case in delta areas where high population densities occur and agriculture is the predominant land use.

Wu et al. (2015) showed that capillary rise plays a main role in supplying the vegetation throughout the season with water, hence a strong dependence of vegetation upon groundwater. Han et al. (2015) applied HYDRUS-1D with a simplified crop growth model for cotton in a north-western part of China and concluded that capillary rise from groundwater contributes to almost $23 \%$ of crop transpiration when the average groundwater depth is $1.84 \mathrm{~m}$. According to Geerts et al. (2008) the contribution from capillary rise to the quinoa [Chenopodium quinoa Willd.] production in the Irpani region (Bolivia) ranges from 8 to $25 \%$ of seasonal crop evapotranspiration (ETc) of quinoa, depending mostly on groundwater table depth and amount of rainfall during the rainy season. The contribution from a groundwater table located approximately 1.5 to $2 \mathrm{~m}$ deep may represent up to $30 \%$ of the soybean [Glycine $\max (\mathrm{L}$.) Merr.] water requirements in sandy pampas (Videla Mensegue et al., 2015).

In $85 \%$ of the area in the Netherlands the average groundwater table is less than $2 \mathrm{~m}$ below the soil surface (De Vries, 2007), where root extraction can induce capillary rise from groundwater. Wesseling and Feddes (2006) report that in summers with a high evapotranspiration demand, crops partially depend on water supply from soil profile storage and induced capillary rise. Van der Gaast et al. (2009), applying the method of Wesseling (1991), found for the Netherlands a maximum capillary flow of $2 \mathrm{~mm} \mathrm{~d}^{-1}$ to the root zone in loamy soils where the groundwater level is at $2.5 \mathrm{~m}$ below the soil surface.

Although the contribution of capillary rise to the total water budget can be significant, it is an often neglected part of the crop water demand in situations of shallow groundwater levels (Awan et al., 2014). The capillary properties of a soil strongly depend on soil type. Rijtema (1971) estimated that loamy soils have an almost 2 times higher capillary rise than sandy soils.

Integrated approaches are needed to relate water availability to crop yield prognosis (Van der Ploeg and Teuling, 2013; Norman, 2013). The importance of capillary rise as supplier of water to crops has been shown by many researchers (e.g. Hooghoudt, 1937; Huo et al., 2012; Talebnejad and Sepaskhah, 2015; Han et al., 2015); however, we found only a few studies that use an integrated modelling approach (Xu et al., 2013; Zipper et al., 2015) to quantify capillary rise for dif- ferent hydrological conditions (including free drainage) using physically based approaches. In this study we explicitly consider the effect of crop type, soil type, weather year and drainage condition on capillary rise. Zipper et al. (2015) introduced the concept of groundwater yield subsidy as the increase in harvested yield $\left(\mathrm{kg} \mathrm{ha}^{-1}\right)$ in the presence of shallow groundwater compared to free-drainage conditions. Following their line we introduce the concept of soil moisture yield subsidy as the additional yield increase in free-drainage conditions due to recirculation of percolated soil moisture.

The driving force for induced capillary rise and recirculation is the difference in soil water potential, referred to as heads, at different soil depths. There are several models available that solve these head differences numerically. Ahuja et al. (2014) evaluated 11 models commonly applied for agricultural water management. Six of these models use simple "bucket" approaches for water storage and have in some cases been extended with more or less empirical options for capillary rise. Five models have the ability to numerically solve Richards equation for water movement in the soil. Examples are HYDRUS (Šimůnek et al., 2008) and SWAP (Feddes et al., 1988; van Dam et al., 2008).

We applied the integrated model SWAP-WOFOST (acronyms for Soil Water Atmosphere Plant - WOrld FOod STudies) to solve head differences and crop yield simulations. Kroes and Supit (2011) applied the same integrated model to quantify the impact of increased groundwater salinity on drought and oxygen of grassland yields in the Netherlands. They recommended further analyses using different crops and different boundary conditions. We now apply this model with different boundary conditions using 45 years of observed weather and three different crops. For the lower boundary we use different hydrologic conditions that influence the vertical flow. For the soil system itself we use a wide range of soil physical conditions. The importance of the soil system was already stated by several authors like Supit (2000). We build on their suggestions and apply the tools for different crops and boundary conditions. Before we applied the model to different boundary conditions, we validated it at the field scale.

This paper quantifies the effects of (intermittent) upward flow on crop growth under different conditions of soil hydrology, soil type and weather. The effects are separately quantified in terms of flow source, namely capillary rise and recirculated percolation water. Therefore, we introduced a synthetic model option and performed a numerical experiment. We studied forage maize, grassland and potatoes and we hypothesize that neglecting upward flow will result in neglecting a considerable amount of soil moisture that is available for crop growth. We quantify this amount and show the importance of including upward flow for crop growth modelling. Our main research questions are the following. (i) Can upward flow with capillary rise and recirculated percolation water as source be quantified separately? (ii) What is the con- 
tribution of capillary rise and recirculated water to crop yield and groundwater recharge?

\section{Materials and methods}

\subsection{Modelling approach}

We applied the coupled SWAP and WOFOST modelling system, using a 1-day time step for the crop model. SWAP (van Dam et al., 2008; Kroes et al., 2017) is a one-dimensional physically based transport model for water, heat and solute in the saturated and unsaturated zone, and includes modules for simulating irrigation practices. The first version of SWAP, called SWATRE, was developed by Feddes et al. (1978). This version also included a module for crop production, CROPR, that applied principles of De Wit (1965) and is still applied in several countries.

SWAP simulates the unsaturated and saturated water flow in the upper part of the soil system, using a numerical solution of the Richards equation:

$$
\frac{\partial \theta}{\partial t}=\frac{\partial\left[K(h)\left(\frac{\partial h}{\partial z}+1\right)\right]}{\partial z}-S_{\mathrm{a}}(h)-S_{\mathrm{d}}(h)-S_{\mathrm{m}}(h),
$$

where $\theta$ is volumetric water content $\left(\mathrm{cm}^{3} \mathrm{~cm}^{-3}\right), t$ is time (d), $K(h)$ is hydraulic conductivity $\left(\mathrm{cm} \mathrm{d}^{-1}\right), h$ is soil water pressure head $(\mathrm{cm}), z$ is the vertical coordinate $(\mathrm{cm})$ taken positively upward, $S_{\mathrm{a}}(h)$ is the soil water extraction rate by plant roots $\left(\mathrm{d}^{-1}\right), S_{\mathrm{d}}(h)$ is the extraction rate by drain discharge in the saturated zone $\left(\mathrm{d}^{-1}\right)$ and $S_{\mathrm{m}}(h)$ is the exchange rate with macro pores $\left(\mathrm{d}^{-1}\right)$.

The numerical solution for this equation uses variable time steps that depend on boundary conditions and an iteration scheme. For example, high fluxes require time steps that are much smaller than 1 day (see Kroes et al., 2017, for a detailed explanation).

Root water extraction and lateral exchange with surface water were accounted for. In this study we did not use the option to exchange water flow with macro pores.

The soil hydraulics were described by the Mualem-van Genuchten relations and the potential evapotranspiration was calculated with the Penman-Monteith equation (Allen et al., 1998). At the bottom boundary water fluxes, supplied by a separate regional hydrological model, were used. Drainage and infiltration through the lateral boundary accounted for the flow to surface water. The surface water system was simulated using a simplified, weir controlled, water balance. Note that the surface water system in its turn interacted with the groundwater system. In previous years, SWAP has been successfully used to study soil-water-atmosphere-plant relationships in many locations with various boundary conditions (e.g. Feddes et al., 1988; Bastiaanssen et al., 2007). See van Dam et al. (2008) for an overview. A recent list is available at http://swap.wur.nl/ (last access: 7 May 2018). Eitzinger et al. (2004), Bonfante et al. (2010), Oster et al. (2012), and Rallo et al. (2012) amongst others tested the model performance.

WOFOST is a crop growth simulation model, its principles are explained by Van Keulen and Wolf (1986). Van Diepen et al. (1989) presented the first WOFOST version. WOFOST is applied in many studies (e.g. Rötter, 1993; Van Ittersum et al., 2003; de Wit and Van Diepen, 2008; Supit et al., 2012; De Wit et al., 2012). Crop assimilation was calculated as a function of solar radiation and temperature, using a 3-point Gaussian integration method accounting for leaf angle distribution and extinction of direct and diffuse light. The assimilation was reduced when water stress occurred. Subsequently, the maintenance respiration was subtracted and the remaining assimilates were partitioned between the plant organs (i.e. leaves, stems, roots and storage organs). For maize and potatoes the partitioning was development-stage dependent. For perennial grass, however, a constant partitioning factor was assumed. By integrating the difference between growth and senescence rates over time, dry weights of various plant organs were established.

In SWAP-WOFOST, crop assimilation depends on the ambient $\mathrm{CO}_{2}$ concentration as well (see: Kroes and Supit, 2011; Supit et al., 2012). To account for unknown residual stress caused by diseases, pests and/or weeds an additional assimilation reduction factor was introduced. The rooting density decreased exponentially with depth. To withdraw water from deeper soil layers for crop uptake, a form of compensatory root uptake was used in case the upper part of the soil was very dry (Jarvis, 1989, 2011). The increasing atmospheric $\mathrm{CO}_{2}$ concentrations during relatively long historical simulation periods ( $>20$ years) was accounted for.

\subsection{Case studies for validation}

SWAP-WOFOST was validated using results of seven case studies at six locations in the Netherlands (Fig. 1), where grassland, maize and potatoes are grown and observations were available from hydrology, soil and crop. The main characteristics of the seven cases are summarized in Table 1. The soil texture ranged from sand to clay. The observations included parameters such as groundwater levels and yields and in some cases soil moisture contents, soil pressure head and evapotranspiration. The weather data were collected from nearby weather stations or from on-site measurements. Observations for case studies 1 and 2 (DM-Grass and DMMaize in Table 1) were available for a period of 22 years (1992-2013) from one field where grassland and maize were grown for respectively 7 and 15 years.

We used the model calibrations carried out by Kroes et al. (2015) and Hack-ten-Broeke et al. (2016) and limited our calibration efforts to parameter values for drought and management (Table 1), focussing on validation of results. Planting and harvest dates were given. Oxygen and drought stress reduced transpiration, which subsequently reduced crop as- 


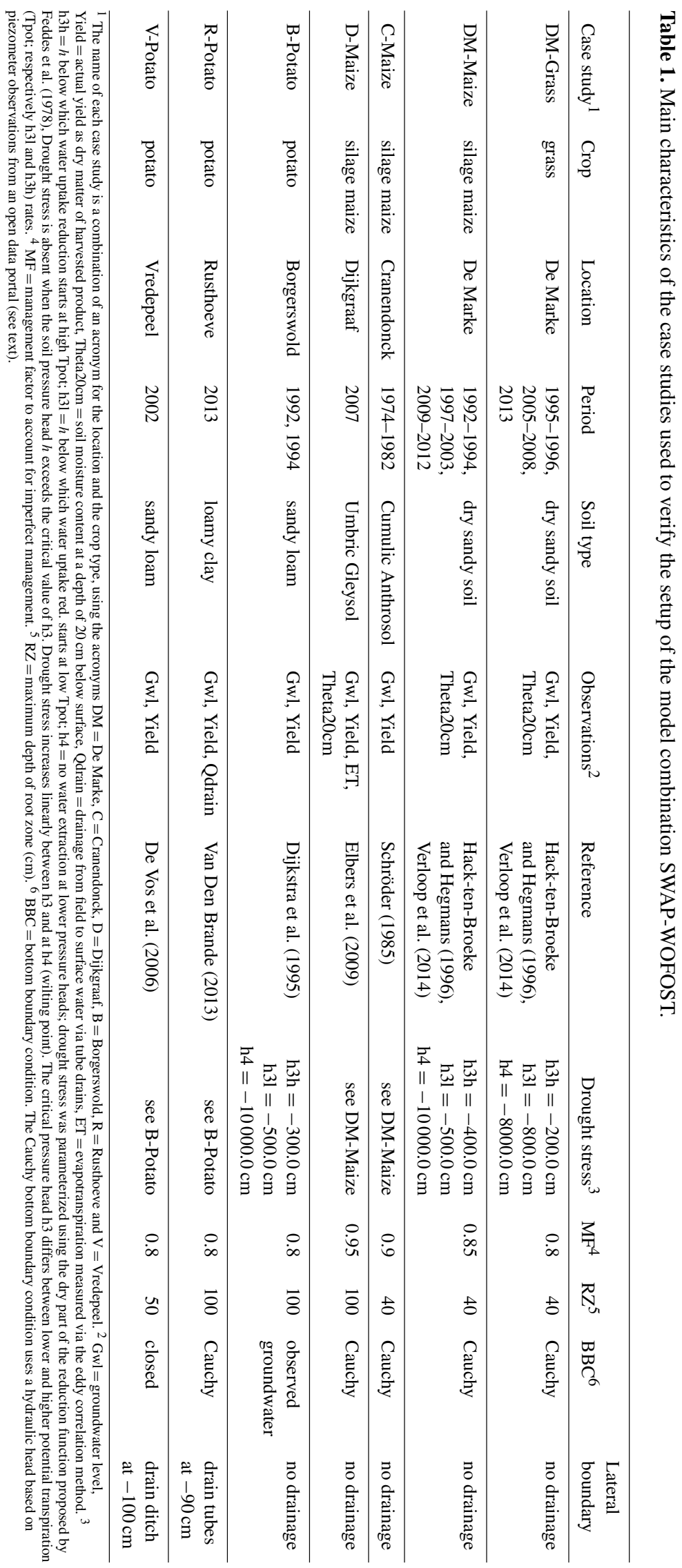




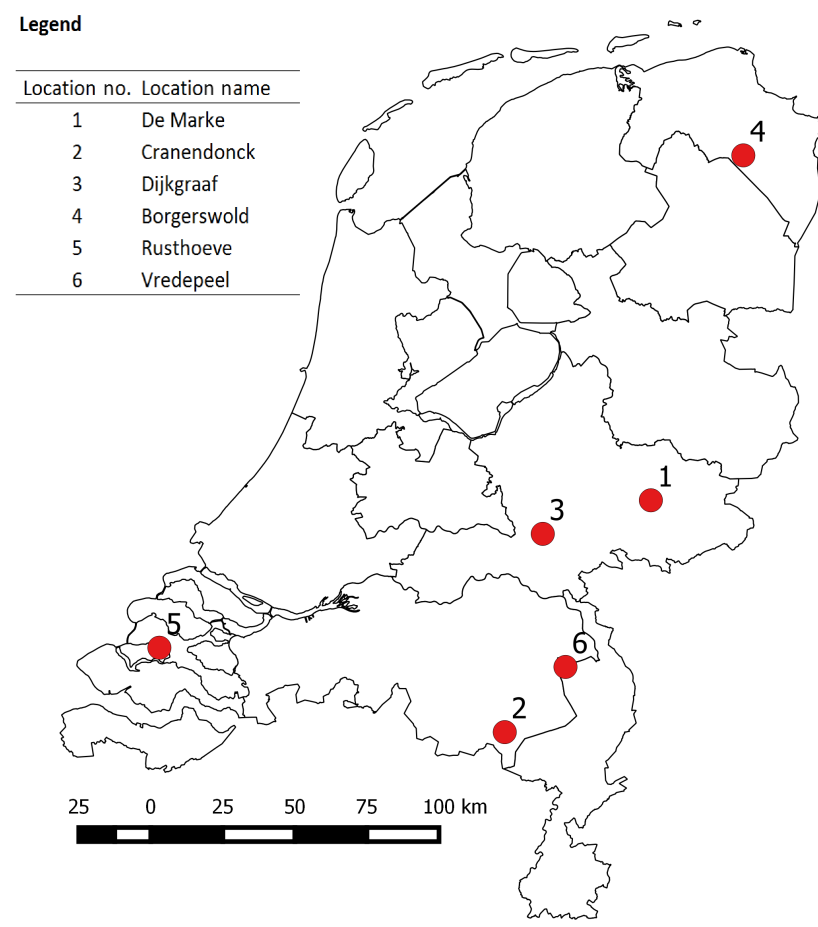

Figure 1. Location of the case studies for grassland, maize and potatoes; location De Marke has a rotation of grassland and maize on the same field.

similation. Oxygen stress was described with the processbased method of Bartholomeus et al. (2008) and parameterized as described by Hack-ten-Broeke et al. (2016). Drought stress was parameterized using the dry part of the reduction function proposed by Feddes et al. (1978). Drought stress was absent when the soil pressure head $h$ exceeded the critical value of $\mathrm{h} 3$. Drought stress increased linearly between $\mathrm{h} 3$ and at $\mathrm{h} 4$ (wilting point). The critical pressure head h3 differed between lower and higher potential transpiration (respectively $h 31$ and $h 3 h$ ) rates. In conditions with drought or oxygen stress, the reduction in stressed parts was partly compensated by extra root water uptake in those parts of the root zone with more favourable soil moisture conditions (Jarvis, 1989, 2011).

For all cases a so-called management factor was used to close the gap between observed and actual yield. The input crop parameters for maize only differed with respect to the management factor which ranges from 0.85 to 0.95 . The management factors were relatively high because the case study locations have good management. It is clear that we missed some processes even though our modelling approach is mechanistic, because it is still relatively simple. Some processes like pests and diseases were not included and may have played a role in the field; the calibration was done on experimental farms where the impact from diseases and pests was minimal.
For potatoes the input crop parameters were kept the same for all three cases (Table 1). Maximum rooting depth for grassland, maize and potatoes were respectively 40, 100 and $50 \mathrm{~cm}$.

Soil water conditions were different for all locations and boundary conditions varied, depending on local situation and available data (Table 1). In most cases a Cauchy bottom boundary condition was applied using a hydraulic head based on piezometer observations from the Dutch Geological Survey (https://www.dinoloket.nl/, last access 14 May 2017). Observed groundwater levels were used as a lower boundary condition for Borgerswold (crop: potato). In two cases a lateral boundary condition was applied with drainage to a surface water system (Table 1). The simulation results were analysed using an R package (Bigiarini, 2013) and the statistics are presented in Table 2.

\subsection{Soil crop experiment to analyse the role of recirculation and capillary rise}

To analyse the impact of soil type on upward soil water flow we modelled soil-crop experiments using 72 soils. Each soil schematization consisted of one or more soil horizons, each with different soil physical properties. The method was described in detail by Wösten et al. (2013a) and the data are available at http://www.wur.nl/nl/show/ Bodemfysische-Eenhedenkaart-BOFEK2012.htm (last access: 7 May 2018). The 72 soils were aggregated from 315 soil units of the 1:50000 Dutch Soil Map using soil hydraulic clustering methods and considering the following properties: maximum groundwater depth, saturation deficit between a certain depth and the soil surface, transmissivity for horizontal water flow, resistance for vertical water flow and availability of water in the root zone (Wösten et al., 2013b). The resulting soil hydraulic properties were subsequently used as SWAP-WOFOST input. The bottom of the soil profile was set at $5.5 \mathrm{~m}$ below the soil surface. At this depth, the simulated root zone soil water fluxes are not affected anymore by the actual depth of the soil profile bottom. The root zone lower boundary was dynamic, it depended on root growth and consequently varied in time.

For each soil we applied three hydrological conditions (Fig. 2) ranging from relatively dry (condition a; Fig. 2a) to relatively wet (condition c; Fig. 2c). The latter is the natural situation in most of the Netherlands. This hydrological condition had a fluctuating groundwater level derived from a national study (Van Bakel et al., 2008). This national study used simulation units which are unique in land use, crop type and drainage conditions resulting in daily groundwater fluctuations. Lateral infiltration and drainage were accounted for ( $q_{\text {infiltration }}$ and $q_{\text {drainage }}$ in Fig. $2 \mathrm{c}$ ). We selected three large simulation units for grassland, maize and potato with longterm average groundwater levels between 40 and $120 \mathrm{~cm}$ below the soil surface, covering respectively 1806, 794 and 58102 ha using data from Van Bakel et al. (2008). See the 
Table 2. Results of Case studies: simulated and observed values.

\begin{tabular}{|c|c|c|c|c|c|c|c|c|c|}
\hline Case study & Name $^{1}$ & Unit & Simulated mean & Observed mean & $\mathrm{ME}^{2}$ & $\mathrm{RMSE}^{3}$ & $\mathrm{NS}^{4}$ & $d^{5}$ & $n^{6}$ \\
\hline \multirow[t]{3}{*}{ DM-Grass } & Yield & $\mathrm{kg} \mathrm{ha}^{-1} \mathrm{yr}^{-1} \mathrm{DM}$ & 11183 & 11049 & 133 & 1347 & 0.6 & 0.9 & 7 \\
\hline & Gwl & m soil & -1.31 & -1.30 & -0.01 & 0.45 & 0.3 & 0.9 & 77 \\
\hline & Theta & $\mathrm{m}^{3} \mathrm{~m}^{-3}$ & 0.28 & 0.27 & 0.01 & 0.05 & 0.5 & 0.9 & 43 \\
\hline DM-Maize & Yield & $\mathrm{kg} \mathrm{ha}^{-1} \mathrm{yr}^{-1} \mathrm{DM}$ & 11593 & 11850 & -257 & 2864 & -3.3 & 0.4 & 14 \\
\hline \multirow[t]{2}{*}{ C-Maize } & Yield & $\mathrm{kg} \mathrm{ha}^{-1} \mathrm{yr}^{-1} \mathrm{DM}$ & 14097 & 13788 & 310 & 2595 & -1.2 & 0.7 & 9 \\
\hline & Gwl & m soil & -1.41 & -1.36 & -0.05 & 0.25 & 0.4 & 0.9 & 61 \\
\hline \multirow[t]{5}{*}{ D-Maize } & Yield & $\mathrm{kg} \mathrm{ha}^{-1} \mathrm{yr}^{-1} \mathrm{DM}$ & 15973 & 16306 & -333 & & & & 1 \\
\hline & LAI & $\mathrm{m}^{2} \mathrm{~m}^{-2}$ & 2.08 & 2.47 & -0.34 & 0.62 & 0.7 & 0.9 & 10 \\
\hline & ETact & $\mathrm{mm} \mathrm{yr}^{-1}$ & 1.33 & 1.93 & -0.61 & 0.89 & 0.5 & 0.9 & 232 \\
\hline & Gwl & m soil & -1.03 & -1.07 & 0.03 & 0.06 & 0.9 & 1.0 & 112 \\
\hline & Theta & $\mathrm{m}^{3} \mathrm{~m}^{-3}$ & 0.29 & 0.27 & 0.01 & 0.03 & 0.5 & 0.8 & 219 \\
\hline \multirow[t]{2}{*}{ B-Potato } & Yield & $\mathrm{kg} \mathrm{ha}^{-1} \mathrm{yr}^{-1} \mathrm{DM}$ & 10543 & 9246 & 1297 & & & & 2 \\
\hline & Gwl & m soil & -1.10 & -1.10 & 0.00 & 0.03 & 1.0 & 1.0 & 123 \\
\hline \multirow[t]{3}{*}{ R-Potato } & Yield & $\mathrm{kg} \mathrm{ha}^{-1} \mathrm{yr}^{-1} \mathrm{DM}$ & 9984 & 8610 & 1374 & & & & 1 \\
\hline & Gwl & m soil & -1.07 & -1.10 & 0.03 & 0.19 & 0.6 & 0.9 & 887 \\
\hline & qDrain & $\mathrm{mm}$ & 1.06 & 0.62 & 0.44 & 1.41 & 0.4 & 0.8 & 1084 \\
\hline \multirow[t]{2}{*}{ V-Potato } & Yield & $\mathrm{kg} \mathrm{ha}^{-1} \mathrm{yr}^{-1} \mathrm{DM}$ & 11071 & 11359 & -288 & & & & 1 \\
\hline & Gwl & m soil & -1.03 & -1.07 & 0.04 & 0.12 & 0.8 & 0.9 & 353 \\
\hline
\end{tabular}

${ }^{1} \mathrm{Gwl}=$ ground water level; Theta $=$ volumic soil moisture content at a depth of $20 \mathrm{~cm}$ below the soil surface; LAI $=$ leaf area index; ETact $=$ actual

evapotranspiration; qDrain = drainage flux. ${ }^{2}$ ME: mean error between simulated ( $\mathrm{sim}$ ) and observed (obs), in the same units of sim and obs, with treatment of missing values. A smaller value indicates better model performance. ${ }^{3}$ RMSE: root mean square error between sim and obs, in the same units of sim and obs, with treatment of missing values. RMSE gives the standard deviation of the model prediction error. A smaller value indicates better model performance. ${ }^{4}$ NS:

Nash-Sutcliffe efficiencies range from $-\infty$ to 1 . Essentially, the closer to 1 the more accurate the model is. NS $=1$ corresponds to a perfect match of modelled to the observed data. NS $=0$ indicates that the model predictions are as accurate as the mean of the observed data. $-\infty<$ NS $<0$ indicates that the observed mean is a better predictor than the model. ${ }^{5} d$ : the index of agreement $(d)$ developed by as a standardized measure of the degree of model prediction error and varies between 0 and 1 . A value of 1 indicates a perfect match, and 0 indicates no agreement at all. The index of agreement can detect additive and proportional differences in the observed and simulated means and variances; however, it is overly sensitive to extreme values due to the squared differences. ${ }^{6} n$ : the number of values used with the four statistical criteria to compare simulated and observed results.

Supplement Sect. S2 for more detail and the Supplement of Kroes and Supit (2011) for an additional explanation of the study from Van Bakel et al. (2008).

The other two conditions (a) and (b) were unsaturated and had no groundwater due to a free-draining bottom boundary ( $q_{\text {leaching, }}$, see Fig. 2 conditions a and b). Condition (a) has been included in this study to explicitly demonstrate the role of recirculation as a source of upward flow. A synthetic modelling option has been implemented to stop upward flow from reaching the root zone, without inhibiting percolation. This option was implemented in the numerical solution of the Richards equation and minimized vertical conductivity just below the root zone in situations when the model simulated upward vertical flow. We did use an implicit scheme for the conductivity in such situations. Code adjustment was necessary to carry out the model experiment (no recirculation) and to demonstrate (quantitatively) the added value of simulating more detailed water fluxes in the soil profile in comparison to bucket approaches. When crop models are used for yield forecasting, these detailed processes play an important role; neglecting them may cause large errors.
The upward flux across the bottom of the root zone can either stem from capillary rise or from percolation water that is recirculated ( $q_{\text {recirc }}$ and $q_{\text {caprise }}$, see Fig. 2 conditions $\mathrm{b}$ and c). The capillary rise (Fig. 2c) has two sources: (i) groundwater and (ii) recirculated percolation water. In all hydrological conditions, percolation across the root zone and leaching across the lower boundary of the model profile occurs ( $q_{\text {percolation }}$ and $q_{\text {leaching }}$ in Fig. 2$)$. All fluxes were calculated using small variable time steps ( $<1$ day); however, results were accumulated to daily net fluxes, which implies that small variations within a day cannot be seen from the results. Recirculation depends on crop water demand, soil hydraulic properties and the presence of soil moisture.

The crop parameters were kept the same as for the case studies, with a few exceptions: (i) for grassland an average management factor of 0.9 was used, (ii) timing of grass mowing was done when a dry matter threshold of $4200 \mathrm{~kg} \mathrm{ha}^{-1}$ DM (dry matter) was exceeded and (iii) for maize and potatoes the harvesting dates were respectively set to 25 October and 15 October.

The three crops and three lower boundary conditions resulted in nine combinations. Each combination was simu- 


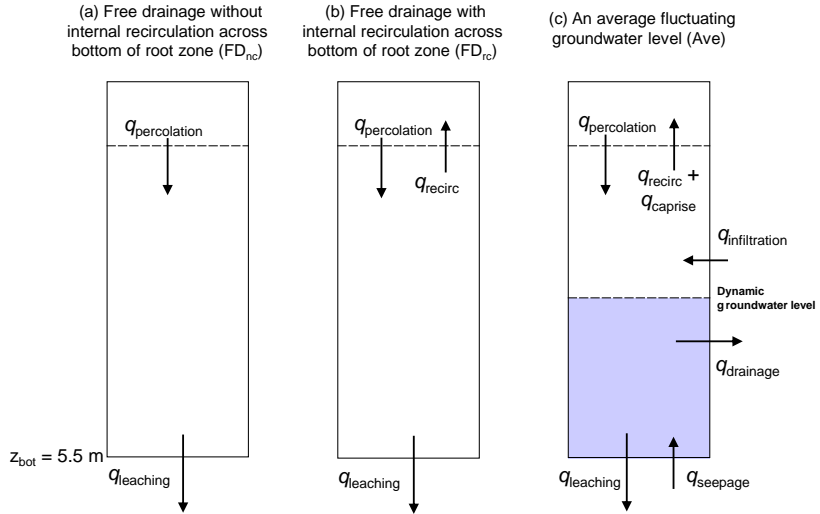

Figure 2. Schematization of three hydrological conditions: (a) free drainage without recirculation across the bottom of the root zone $\left(\mathrm{FD}_{\mathrm{nc}}\right)$; (b) free drainage with recirculation across bottom of root zone (FDrc); (c) average fluctuating groundwater level (Ave). Conditions (a) and (b) have free-draining bottom boundary conditions without groundwater. Condition (a) is artificially created to explicitly demonstrate the role of recirculating percolation resulting in upward flow to the root zone. Condition (b) is a common free-drainage situation which includes upward flow due to recirculating percolation water. Condition (c) is the natural situation in most of the Netherlands. This hydrological condition has a fluctuating groundwater level derived from a national study (Van Bakel et al., 2008).

lated with 72 soils for a period of 45 years (1971-2015) with meteorological data from the station De Bilt (KNMI, 2016). In a subsequent analysis we grouped the results of these 72 soils to five main soil groups: clay, loam, peat, peat moor and sand (Fig. 3) to be able to analyse the impact at grouped soil types.

The implementation of the synthetic modelling option is explained in Sect. S4 with references to the open-source model SWAP version 4.0.1, which was used to carry out all the simulations.

\section{Results}

\subsection{Case studies for validation}

The first two case studies are from one location (De Marke), where a grassland-maize rotation was practised. The results show that the hydrological conditions (Fig. 4 and Table 2) were simulated accurately for those years for which observed data were available (1991-1995). From 1995-1997 the groundwater levels dropped as a result of low precipitation (about $700 \mathrm{~mm} \mathrm{yr}^{-1}$ ). The autumn of the year 1998 showed rising groundwater levels that corresponded well with very wet conditions at that time. The simulated grassland yields were overestimated by $133 \mathrm{~kg} \mathrm{ha}^{-1} \mathrm{DM}$ and the simulated maize yields were underestimated by $257 \mathrm{~kg} \mathrm{ha}^{-1}$ DM, and differences were well within acceptable ranges (Fig. 5 and Table 2).

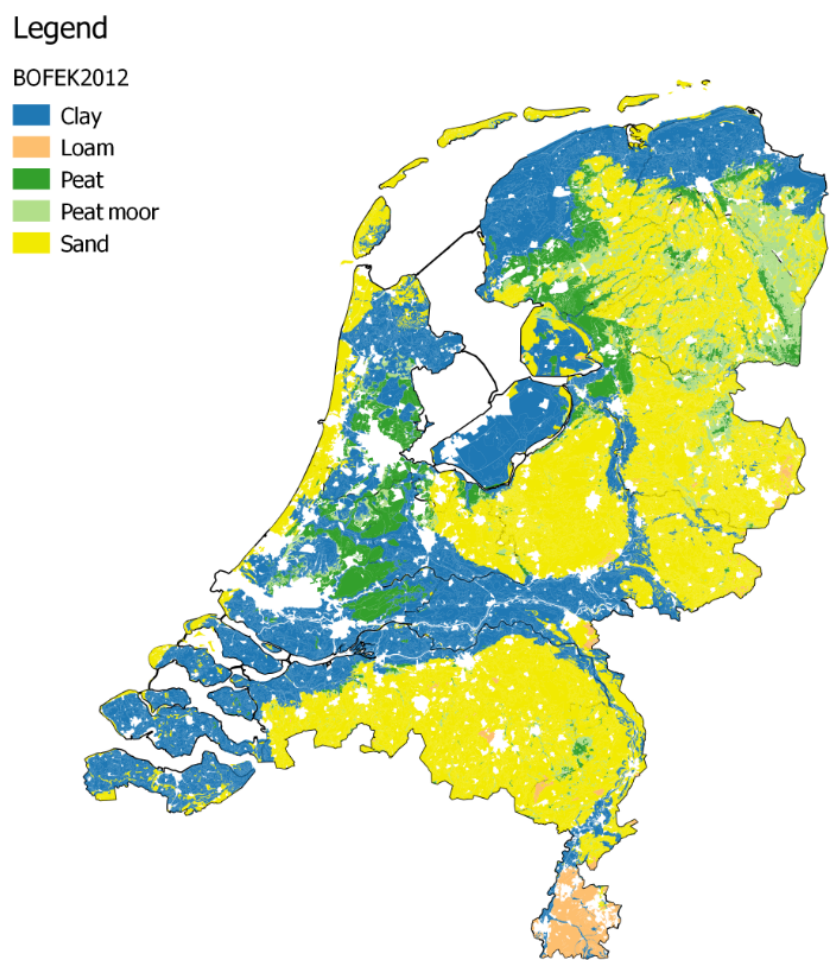

Figure 3. Five grouped soil types, based on 72 soils of the Soil Physical Map of the Netherlands (Wösten et al., 2013).

For the other two maize case studies (C-Maize and DMaize) groundwater levels and soil moisture were well simulated (Table 2). The simulated maize yields (Table 2) were less acceptable for case C-Maize as indicated by a zero or negative Nash-Sutcliffe efficiency (NS), which suggests that the observed mean was a better predictor than the model. One should consider that the NS efficiency is sensitive to sample size and outliers. In 1976, a very dry year, the soil hydrology dynamics and the resulting yield were well captured. The yield of case study D-Maize had a small bias of $333 \mathrm{~kg} \mathrm{ha}^{-1}$ DM between observed and simulated values.

The simulated hydrological conditions for the three fields of the potato cases - B-Potato, R-Potato and V-Potato showed a good fit with the observed (Table 2). The simulated yields (Table 2) showed the largest deviation from the observed for the case B-Potato. The more recent experiments of potato case studies, R-Potato and V-Potato, showed differences between simulated and observed yields of respectively 1374 and $-288 \mathrm{~kg} \mathrm{ha}^{-1}$ DM (Table 2). These case studies unfortunately covered only 1 year. The case R-Potato performed less due to the complex situation in the subsoil with drainage conditions that require more observations to improve the simulations.

However, one has to bear in mind that perfect calibration is not the objective of this study; we used calibration values from earlier studies (Kroes et al., 2015; Hack-ten-Broeke et al., 2016). No detailed assimilation measurements were exe- 

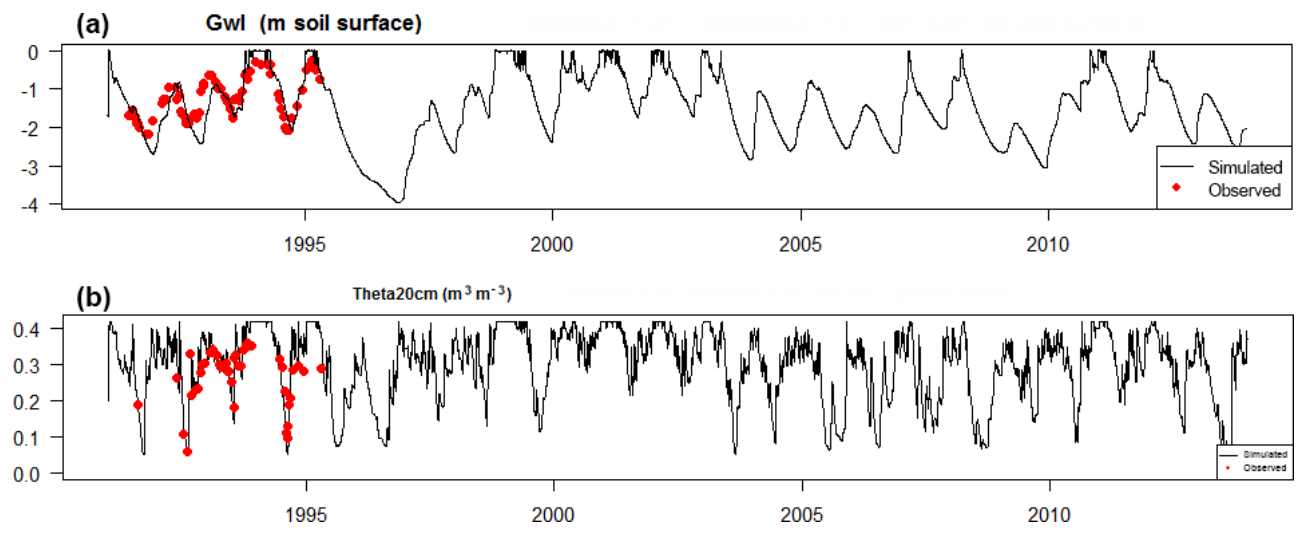

Figure 4. Results of case studies for grassland at location 1 (De Marke): (a) for groundwater level (Gwl in metres soil surface); (b) for soil moisture content (Theta $20 \mathrm{~cm}$ in $\mathrm{m}^{3} \mathrm{~m}^{-3}$ ) at $20 \mathrm{~cm}$ below the soil surface.
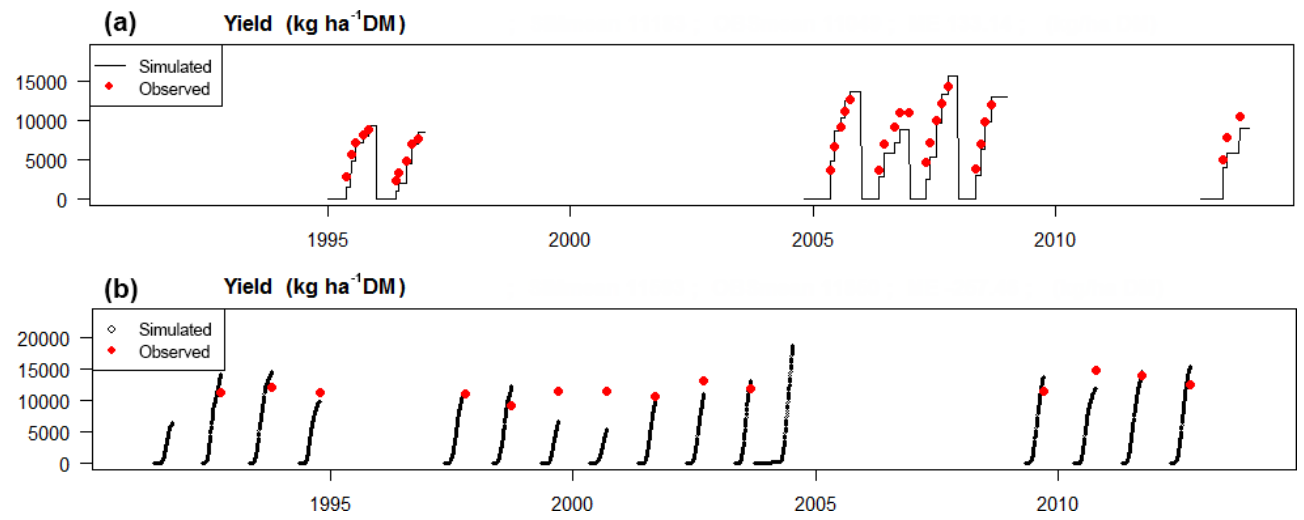

Figure 5. Results of case studies at location 1 (De Marke): observed yields ( $\mathrm{kg} \mathrm{ha}^{-1} \mathrm{DM}$ ) as red dots and simulated yields as black lines or as black dots: (a) for yields ( $\left.\mathrm{kg} \mathrm{ha}^{-1} \mathrm{DM}\right)$ of grassland; (b) for yields $\left(\mathrm{kg} \mathrm{ha}^{-1} \mathrm{DM}\right)$ of maize.

cuted on the fields and the meteorological data were not measured on site, but taken from meteorological stations sometimes more than $30 \mathrm{~km}$ away. Furthermore, no detailed information concerning fertilizer applications and soil carbon was available, therefore we considered it constant in time.

Even though some yields were not accurate enough to satisfy statistical criteria for good model performance, we believe that the dynamics of soil hydrology and crop yield were acceptably captured. With more field information and calibration, a better result could be achieved but we think that current tuning of SWAP-WOFOST for the three crops allowed for an application at a larger scale with various hydrological boundary conditions.

Before the analysis at a larger scale we simulated the impact of upward flow for the case studies. We carried out additional simulations without upward flow towards the root zone, using the specially programmed synthetic model option. Results of these three cases are given in Table 3 for the situation with and without upward flow. This table shows that suppressing upward flow lowered yields by 6,3 and $20 \%$ respectively for grassland, maize and potato. The groundwater recharge was reduced with respectively 3,4 and $94 \%$ (Table 3). Detailed results can be found in Sect. S1. In Sect. S4 input data for case 3 (V-Potato) can be found. In a next step, we carried out a larger-scale experiment to quantify this impact for different soil crop and climate conditions.

\subsection{Soil crop experiment to analyse the role of capillary rise}

The three crops from the case studies were simulated with 72 soils from the national database using three different bottom boundary conditions and 45 years with weather from 1970 to 2015.

Results of simulated upward flow of 45 years of weather, 72 soils and three lower boundary conditions are summarized with mean values in Table 4. The highest values for upward flow to the root zone during crop growth were found for average groundwater conditions (Ave) with long-term mean values for grassland, maize and potatoes of respectively 194, 74 and $112 \mathrm{~mm} \mathrm{yr}^{-1}$. Differences among hydrological conditions at the bottom of the root zone were caused by differences in weather, growing season, dynamic position of the 
Table 3. Results of the case studies: values and differences in yield, capillary rise and percolation fluxes resulting from simulations with and without capillary rise.

\begin{tabular}{llrrrlrr}
\hline \multirow{2}{*}{ Case study } & \multirow{2}{*}{ Model result } & \multicolumn{2}{c}{ Condition } & Differences & Unit & Differences $(\%)$ \\
\cline { 2 - 4 } & & $\mathrm{A}^{2}$ & $\mathrm{~B}^{3}$ & & $\mathrm{~A}-\mathrm{B}$ & & $100 \times(\mathrm{A}-\mathrm{B}) / \mathrm{A}$ \\
\hline \multirow{2}{*}{ DM-Grass } & $Y_{\text {act }}$ & 12928 & 12213 & 715 & $\mathrm{~kg} \mathrm{ha}^{-1}$ season $^{-1} \mathrm{DM}$ & 6 \\
& $q_{\text {caprise }}$ & 30 & 0 & 30 & $\mathrm{~mm} \mathrm{season}^{-1}$ & 100 \\
& $q_{\text {percolation }}$ & 313 & 305 & 9 & $\mathrm{~mm} \mathrm{season}^{-1}$ & 3 \\
\hline \multirow{2}{*}{ DM-Maize } & $Y_{\text {act }}$ & 12803 & 12788 & 15 & $\mathrm{~kg} \mathrm{ha}^{-1}$ season $^{-1} \mathrm{DM}$ & 0 \\
& $q_{\text {caprise }}$ & 7 & 0 & 7 & $\mathrm{~mm} \mathrm{season}^{-1}$ & 100 \\
& $q_{\text {percolation }}$ & 91 & 88 & 3 & $\mathrm{~mm} \mathrm{season}^{-1}$ & 4 \\
\hline V-Potato & $Y_{\text {act }}$ & 11071 & 8877 & 2194 & $\mathrm{~kg} \mathrm{ha}^{-1}$ season $^{-1} \mathrm{DM}$ & 20 \\
& $q_{\text {caprise }}$ & 101 & 0 & 101 & $\mathrm{~mm} \mathrm{season}^{-1}$ & 100 \\
& $q_{\text {percolation }}$ & 16 & 1 & 15 & $\mathrm{~mm} \mathrm{season}^{-1}$ & 94 \\
\hline
\end{tabular}

\footnotetext{
${ }^{1}$ Cases studies DM-Grass and DM-Maize were simulated for limited periods of respectively 2005-2008 and 1991-1994 to have a continuous sequence of years. Case study V-Potato was simulated for 1 year. ${ }^{2}$ Condition A has actual bottom boundary conditions according to column BBC in Table $1 .{ }^{3}$ Condition B has actual bottom boundary conditions according to column BBC in Table 1 , but without capillary rise to root zone.
}

Table 4. Results of soil crop experiments: mean values of six model results from three different hydrological conditions: FDnc (free drainage with no recirculation), FDrc (free drainage with recirculation) and Ave (average drainage conditions).

\begin{tabular}{llrrrl}
\hline Crop & Model Result & $\mathrm{FD}_{\text {nc }}$ & $\mathrm{FD}_{\mathrm{rc}}$ & Ave & Unit \\
\hline \multirow{2}{*}{ Grassland } & $Y_{\text {act }}$ & 10494 & 12147 & 14177 & $\mathrm{~kg} \mathrm{ha}^{-1} \mathrm{season}^{-1} \mathrm{DM}$ \\
& $q_{\text {caprise }}$ & & & 194 & $\mathrm{~mm} \mathrm{season}^{-1}$ \\
& $q_{\text {recirc }}$ & 0 & 78 & & $\mathrm{~mm} \mathrm{season}^{-1}$ \\
& $q_{\text {percolation }}$ & 317 & 338 & 380 & $\mathrm{~mm} \mathrm{season}^{-1}$ \\
& $q_{\text {seepage }}$ & 0 & 0 & 227 & $\mathrm{~mm} \mathrm{yr}^{-1}$ \\
& $q_{\text {leaching }}$ & 301 & 257 & 0 & $\mathrm{~mm} \mathrm{yr}^{-1}$ \\
\hline \multirow{2}{*}{ Maize } & $Y_{\text {act }}$ & 12318 & 12378 & 12643 & $\mathrm{~kg} \mathrm{ha}^{-1}$ season $^{-1} \mathrm{DM}$ \\
& $q_{\text {caprise }}$ & & & 74 & $\mathrm{~mm} \mathrm{season}^{-1}$ \\
& $q_{\text {recirc }}$ & 0 & 17 & & $\mathrm{~mm} \mathrm{season}^{-1}$ \\
& $q_{\text {percolation }}$ & 52 & 57 & 47 & $\mathrm{~mm} \mathrm{season}^{-1}$ \\
& $q_{\text {seepage }}$ & 0 & 0 & 155 & $\mathrm{~mm} \mathrm{yr}^{-1}$ \\
& $q_{\text {leaching }}$ & 396 & 394 & 0 & $\mathrm{~mm} \mathrm{yr}^{-1}$ \\
\hline \multirow{2}{*}{ Potato } & $Y_{\text {act }}$ & 8864 & 9521 & 10365 & $\mathrm{~kg} \mathrm{ha}^{-1} \mathrm{season}^{-1} \mathrm{DM}$ \\
& $q_{\text {caprise }}$ & & & 112 & $\mathrm{~mm} \mathrm{season}^{-1}$ \\
& $q_{\text {recirc }}$ & 0 & 42 & & $\mathrm{~mm} \mathrm{season}^{-1}$ \\
& $q_{\text {percolation }}$ & 39 & 50 & 73 & $\mathrm{~mm} \mathrm{season}^{-1}$ \\
& $q_{\text {seepage }}$ & 0 & 0 & 291 & $\mathrm{~mm} \mathrm{yr}^{-1}$ \\
& $q_{\text {leaching }}$ & 432 & 416 & 0 & $\mathrm{~mm} \mathrm{yr}^{-1}$ \\
\hline
\end{tabular}

root zone and demand of root water uptake. Even in freedrainage situations the upward flow to the root zone caused by soil water recirculation was considerable, ranging from 17 to $78 \mathrm{~mm}$ long-term average ( $\mathrm{FD}_{\mathrm{rc}}$ in Table 4$)$. In freedraining soils the variation in upward flow to the root zone ranged from about $10 \mathrm{~mm}$ in wet and cold to $120 \mathrm{~mm}$ in dry and warm years with a high evaporative demand (Fig. 6a). In general, upward flow was highest in loamy soils where soil physical conditions were optimal. Especially in the presence of a groundwater level, differences in upward flow between soils were relatively small compared to differences among years and within one grouped soil type (Fig. 7b).

The upward flow was inversely related to the rooting depth: the larger the rooting depth the smaller the upward flow. Grassland, potatoes and maize had rooting depths of respectively 40,50 and $100 \mathrm{~cm}$ and an upward flow of respec- 
(a) Upward flux across bottom root zone ( $\mathrm{mm}$ crop season ${ }^{-1}$ )

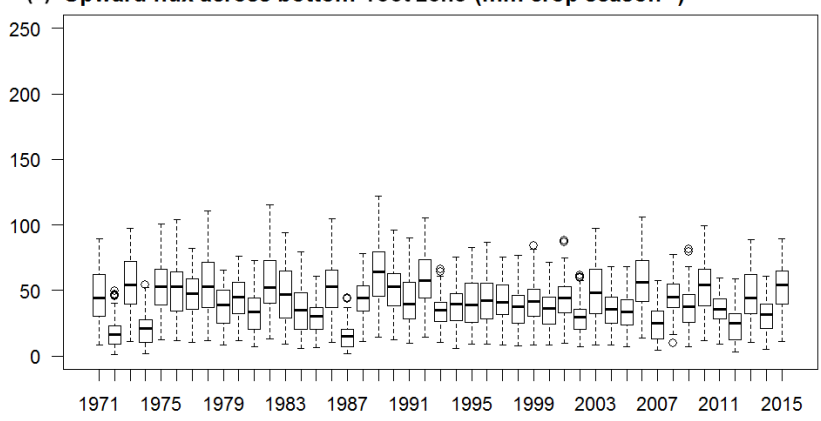

(b)

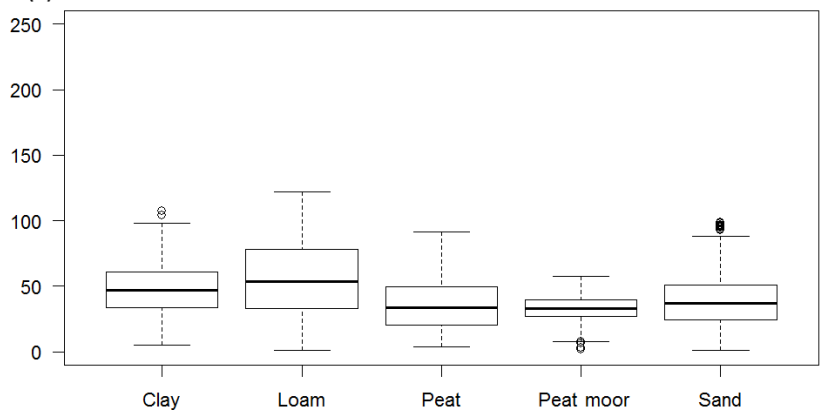

Figure 6. Results of the soil-crop experiment for potato: upward flux across the bottom of the root zone ( $q_{\text {recirc }}$ in $\mathrm{mm} \mathrm{crop} \mathrm{season}^{-1}$ ) for hydrological conditions with free drainage (FDrc): (a) for results for all 72 soils for the period 1971-2015; (b) for results as box plots for clustered soil types.

tively 194, 112 and $74 \mathrm{~mm}$ per growth season (Table 4). Note that the high value for perennial grassland was also caused by a much longer growing season. The percolation was highest for grassland for the same reasons (Table 4). These high values were largely due to the precipitation excess during winter in the Netherlands.

Upward seepage across the bottom boundary did not occur in the free-drainage conditions (Fig. 2a, b). Leaching was highest (Table 4) in the synthetic free-drainage condition without capillary rise (Fig. 2a). Note that the values in Table 4 for seepage and leaching were given for a calendar year, whereas the other mean values were given for a growing season. Yearly values were used for the bottom boundary because these values give an indication for the yearly deeper groundwater recharge, which may also be influenced by variations in vertical fluxes close to the root zone during the remainder of the year. The leaching flux at $5.5 \mathrm{~m}$ depth (Table $4, q_{\text {leaching }}$ ) increased when upward flow was suppressed (lower transpiration, more groundwater recharge), with respectively 44, 2 and $16 \mathrm{~mm} \mathrm{yr}^{-1}$ for grassland, maize and potatoes. The shallow groundwater in Dutch conditions (Fig. 2c) often does not have leaching at greater depth because excess precipitation or upward seepage is discharged via drainage systems. The average condition we used had no leaching but seepage of 227,155 and $291 \mathrm{~mm} \mathrm{yr}^{-1}$ for grassland, maize and potatoes (Table $4, q_{\text {seepage }}$ ).
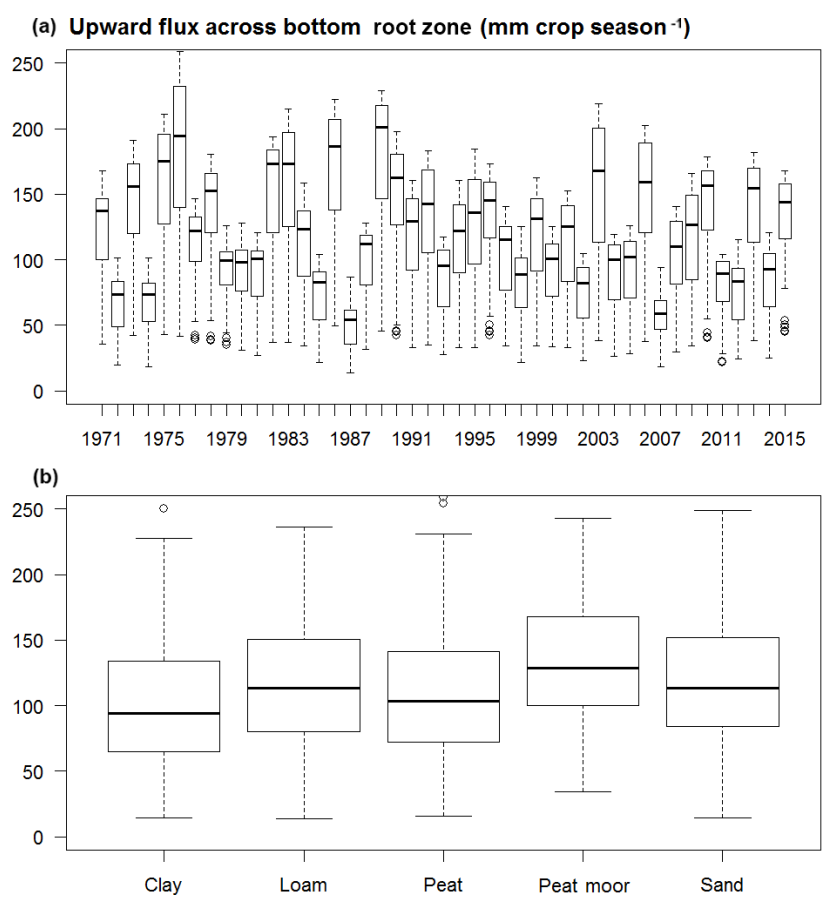

Figure 7. Results of the soil-crop experiment for potato: upward flux across the bottom of the root zone ( $q_{\text {caprise }}$ in mm cropseason ${ }^{-1}$ ) for hydrological conditions with average groundwater level (Ave): (a) for results for all 72 soils for the period 1971-2015; (b) for results as box plots for clustered soil types.

As can be expected, the synthetic condition without upward flow and without groundwater (Fig. 2a) had the lowest simulated mean yields for all crops (Table 4). The highest mean yields were simulated when average groundwater situations including capillary rise were considered (Table 4, Ave). The relative mean yield increase was lowest for maize and highest for grassland (Table 5), which was probably caused by the difference in rooting depth.

The simulation results with three different lower boundary conditions (Fig. 2 conditions a, b and c) were also compared by subtraction. The subtraction enables a quantification of the contribution of the two different sources of upward flow: groundwater and recirculating percolation water.

The elimination of recirculating percolation water to the root zone in free-drainage conditions (synthetic condition a compared to b, Fig. 2) reduced grassland, maize and potato yields with respectively 14,0 and $7 \%$ (Table 5). The higher yields were caused by upward flow using recirculating percolation water as source.

A comparison between situations with free drainage (condition b, Fig. 2) with average groundwater levels (condition c, Fig. 2) showed a similar yield reduction: respectively 14 , 2 and $8 \%$. The higher yields were caused by capillary rise with groundwater and recirculation as source.

When one compares situations with free-drainage conditions without upward flow (synthetic condition a, Fig. 2) with 
Table 5. Results of soil-crop experiments: differences (\%) between results from three different hydrological conditions: FDnc (free drainage with no recirculation), FDrc (free drainage with recirculation) and Ave (average drainage conditions).

\begin{tabular}{llrrr}
\hline \multirow{2}{*}{ Crop } & Model Result & \multicolumn{3}{c}{ Differences $(\%)$} \\
\cline { 3 - 5 } & & $\begin{array}{r}100 \times\left(\mathrm{FD}_{\mathrm{rc}}-\mathrm{FD}_{\mathrm{nc}}\right) \\
\mathrm{FD}_{\mathrm{rc}}\end{array}$ & $\begin{array}{r}100 \times(\text { Ave-FD } \\
\text { rc })\end{array}$ & $\begin{array}{r}100 \times(\text { Ave-FD } \\
\text { nc })\end{array}$ \\
\hline \multirow{2}{*}{ grassland } & $Y_{\text {act }}$ & 14 & 14 & 26 \\
& $q_{\text {percolation }}$ & 6 & 11 & 17 \\
\hline \multirow{2}{*}{ maize } & $Y_{\text {act }}$ & 0 & 2 & 3 \\
& $q_{\text {percolation }}$ & 9 & -22 & -11 \\
\hline \multirow{2}{*}{ potato } & $Y_{\text {act }}$ & 7 & 8 & 14 \\
& $q_{\text {percolation }}$ & 22 & 31 & 46 \\
\hline
\end{tabular}

average groundwater levels (condition c) yield reductions of grassland, maize and potatoes were respectively 26,3 and $14 \%$ (Table 5) or respectively about $3.7,0.3$ and $1.5 \mathrm{tha}^{-1}$ DM (Table 4). These yield differences quantify the contribution to the sum of the two different sources of upward flow: groundwater and recirculating percolation water.

The impact of upward flow on groundwater recharge was highest for potatoes and lowest for maize. For grassland, maize and potatoes differences between downward flux across the bottom of the root zone ( $q$ percolation in Fig. 2) of three hydrological conditions were calculated of respectively $17,-11$ and $46 \%$ ( $q$ percolation in Table 5$)$ or $63,-5$ and $34 \mathrm{~mm}$ ( $q$ percolation in Table 4$)$. Low recharge values for maize were caused by deeper rooting systems which reduced these differences because groundwater levels were closer to the bottom of the root zone. For potatoes this difference in yield did reach values of more than $4 \mathrm{tha}^{-1} \mathrm{DM}$ in stress conditions (Table 6). The results are presented in more detail in the Sect. S3.

\section{Discussion}

The case studies and soil-crop experiments in this paper demonstrate the combined interaction of recirculation and capillary rise on crop yields. This impact is clearly present in situations where a groundwater level is present (85\% of NL) but also in free-draining situations the impact of upward flow is considerable. According to our simulation results, grassland, maize and potato yields increased with respectively 14 , 0 and $7 \%$ in free-drainage conditions when upward flow was included (Table 5). This increase was mainly caused by internal recirculation, i.e. a part of the downward flux past the root zone was redirected upward to the root zone as a result of gradient-driven flow. When upward flow also has groundwater as a source, simulated yields increased by another 14, 2 and $8 \%$ respectively. This increase was supported by a stronger capillary rise due to proximity to the groundwater. Comparing the simple simulations (no upward flow, no groundwater influence) to those with an average groundwater level and capillary rise shows yield increases of 26, 3 and $14 \%$. About half of these yield increases were caused by internal recirculation as occurs in free-drainage conditions and the other half was caused by an increased upward capillary flow from the groundwater.

Crop models that apply the bucket approach consider the soil system as a reservoir with only percolation and no upward flow (an overview with a model comparison is provided by Ahuja et al., 2014). Such models do not account for soil moisture redistribution within and below the root zone. Similar to Guderle and Hildebrand (2015) our simulation results show that a detailed vertical flow improves predictions of root water uptake. Bucket models generally overestimate drought stress and groundwater recharge and subsequently underestimate crop yield. The irrigation demand may be overestimated as well. The high percolation may also result in overestimation of groundwater recharge (leaching). Groundwater depth is important, because it determines the distance that the capillary flux has to bridge to reach the root zone and should be accounted for in crop modelling.

In the ideal situation one should compare the bucket approach to the approach with full simulation of capillary rise and recirculation using independent data sets. However, the measured data sets were insufficient to calibrate and validate the soil and crop parameters in such detail that they could allow proper statistical evaluation of the two approaches. The calibration of both model approaches had too much freedom with the available data sets, which upset a reliable validation. Therefore, we used the measured data sets to illustrate that with common soil and crop input values, SWAP-WOFOST yielded realistic and plausible results for the crops considered in this study. Further, crop growth and soil water flow were simulated by SWAP-WOFOST with novel concepts. Therefore, we may expect that the model itself can be used to show the effect on crop yield of different boundary conditions with respect to zero flux, recirculation and capillary rise.

Our hypothesis is that the process of recirculation makes crop modelling more accurate. 
Table 6. Results for potatoes of soil crop experiments for each clustered soil type: capillary rise, recirculation and yield from three different hydrological conditions: FDnc (Free Drainage with No reCirculation), FDrc (Free Drainage with Recirculation) and Ave (Average Drainage conditions). Results for upward flow of FDnc are zero and therefore not given.

\begin{tabular}{|c|c|c|c|c|c|c|c|c|}
\hline \multirow{2}{*}{$\begin{array}{l}\text { Hydrological } \\
\text { condition }\end{array}$} & & \multirow[t]{2}{*}{ Statistic } & \multicolumn{5}{|c|}{ Values per clustered soil type } & \multirow[t]{2}{*}{ Unit } \\
\hline & & & Clay & Loam & Peat & Moor & Sand & \\
\hline \multirow[t]{5}{*}{$\mathrm{FD}_{\mathrm{rc}}$} & \multirow[t]{5}{*}{$q_{\text {recirc }}$} & $\min$ & 5 & 1 & 4 & 8 & 1 & mm crop $^{-1}$ season \\
\hline & & lower quartile & 34 & 33 & 20 & 27 & 24 & $\mathrm{~mm} \mathrm{crop}^{-1}$ season \\
\hline & & median & 47 & 54 & 34 & 33 & 37 & $\mathrm{~mm} \mathrm{crop}^{-1}$ season \\
\hline & & upper quartile & 61 & 78 & 50 & 39 & 51 & mm crop $^{-1}$ season \\
\hline & & $\max$ & 98 & 122 & 91 & 58 & 88 & $m m$ crop $^{-1}$ season \\
\hline \multirow[t]{5}{*}{ Ave } & \multirow{5}{*}{$q_{\text {caprise }}$} & $\min$ & 14 & 14 & 15 & 34 & 15 & $m m$ crop $^{-1}$ season \\
\hline & & lower quartile & 65 & 80 & 72 & 100 & 84 & $m m$ crop $^{-1}$ season \\
\hline & & median & 94 & 113 & 104 & 129 & 113 & $\mathrm{~mm} \mathrm{crop}^{-1}$ season \\
\hline & & upper quartile & 134 & 151 & 141 & 168 & 152 & mm crop ${ }^{-1}$ season \\
\hline & & $\max$ & 227 & 236 & 231 & 243 & 249 & $\mathrm{~mm} \mathrm{crop}^{-1}$ season \\
\hline \multirow[t]{5}{*}{$\mathrm{FD}_{\mathrm{nc}}$} & \multirow[t]{5}{*}{$Y_{\mathrm{act}}$} & $\min$ & 3.1 & 5.4 & 2.8 & 2.8 & 1.2 & $1000 \mathrm{~kg} \mathrm{ha}^{-1} \mathrm{DM}$ \\
\hline & & lower quartile & 7.4 & 8.7 & 7.5 & 6.9 & 6.9 & $1000 \mathrm{~kg} \mathrm{ha}^{-1} \mathrm{DM}$ \\
\hline & & median & 9.6 & 10.3 & 9.8 & 9.3 & 9.2 & $1000 \mathrm{~kg} \mathrm{ha}^{-1} \mathrm{DM}$ \\
\hline & & upper quartile & 10.7 & 10.9 & 10.7 & 10.7 & 10.7 & $1000 \mathrm{~kg} \mathrm{ha}^{-1} \mathrm{DM}$ \\
\hline & & $\max$ & 12.2 & 12.2 & 12.2 & 12.2 & 12.2 & $1000 \mathrm{~kg} \mathrm{ha}^{-1} \mathrm{DM}$ \\
\hline \multirow[t]{5}{*}{$\mathrm{FD}_{\mathrm{rc}}$} & \multirow[t]{5}{*}{$Y_{\text {act }}$} & $\min$ & 5.0 & 7.5 & 4.8 & 3.4 & 3.3 & $1000 \mathrm{~kg} \mathrm{ha}^{-1} \mathrm{DM}$ \\
\hline & & lower quartile & 8.5 & 9.6 & 8.4 & 7.6 & 7.8 & $1000 \mathrm{~kg} \mathrm{ha}^{-1} \mathrm{DM}$ \\
\hline & & median & 10.2 & 10.6 & 10.1 & 9.8 & 9.9 & $1000 \mathrm{~kg} \mathrm{ha}^{-1} \mathrm{DM}$ \\
\hline & & upper quartile & 10.9 & 11.1 & 10.9 & 10.8 & 10.8 & $1000 \mathrm{~kg} \mathrm{ha}^{-1} \mathrm{DM}$ \\
\hline & & $\max$ & 12.4 & 12.4 & 12.4 & 12.4 & 12.4 & $1000 \mathrm{~kg} \mathrm{ha}^{-1} \mathrm{DM}$ \\
\hline \multirow[t]{5}{*}{ Ave } & \multirow[t]{5}{*}{$Y_{\text {act }}$} & $\min$ & 7.4 & 8.0 & 7.8 & 7.8 & 7.7 & $1000 \mathrm{~kg} \mathrm{ha}^{-1} \mathrm{DM}$ \\
\hline & & lower quartile & 9.6 & 9.8 & 9.8 & 9.8 & 9.7 & $1000 \mathrm{~kg} \mathrm{ha}^{-1} \mathrm{DM}$ \\
\hline & & median & 10.5 & 10.7 & 10.7 & 10.7 & 10.7 & $1000 \mathrm{~kg} \mathrm{ha}^{-1} \mathrm{DM}$ \\
\hline & & upper quartile & 11.1 & 11.2 & 11.1 & 11.2 & 11.1 & $1000 \mathrm{~kg} \mathrm{ha}^{-1} \mathrm{DM}$ \\
\hline & & $\max$ & 12.6 & 12.6 & 12.6 & 12.6 & 12.6 & $1000 \mathrm{~kg} \mathrm{ha}^{-1} \mathrm{DM}$ \\
\hline
\end{tabular}

To demonstrate and support our hypothesis we added another case study. This is reported in Sect. S5. In this section we demonstrated the difference in soil water pressure head in the upper part of the root zone as caused by drying of the soil due to a lack of recirculating water in the hydrological condition (Fig. 2a). This resulted in a lowering of average yields with $609 \mathrm{~kg} \mathrm{ha}^{-1}$ (from 7132 to $7741 \mathrm{~kg} \mathrm{ha}^{-1} \mathrm{DM}$, which is about $9 \%$ yield reduction due to recirculation. This supports the recommendation to use tools that support this process of recirculation in conditions where the vertical water fluxes across the root zone are relatively high. This will clearly be the case in delta regions where you occasionally have a precipitation excess.

A bucket approach generally underestimates water availability in the rooting zone and consequently overestimates drought stress (Boogaard et al., 2013). We suggest to generate additional relations for the contribution of recirculation and capillary rise to upward flow to the root zone. Such an approach has been used in AQUACROP to derive a relation between capillary rise and groundwater (Van Gaelen et al.,
2017). Another approach is to calibrate the conceptual parameters of a bucket model with agro-hydrological models like SWAP as done by Romano et al. (2011).

Our analysis shows that soil properties and soil profile layering are important because differences in soil hydraulic properties influence vertical water flow. High upward flow values were found in loamy soils as was expected (Table 6, max row), but if water stress was high and upward flow was low the influence of soil type decreased and low upward flow values were found for loamy soils (Table 6 , min row). Comparing the minimum yield values showed that there was a large difference between these soil types in free-drainage conditions with and without upward flow. This means that the storage capacity of loamy soils was larger than the one of sandy soils as could be expected. The yield variation between soil types in water stress conditions was large and illustrated the need for a proper soil schematization, especially in stress full hydrological conditions. As the influence of recirculation increased, the yield variation became less and the influence of soil type decreased. In situations without water stress 
the soil type was less important. In conditions where groundwater and capillary rise occurred (Ave), yield variation was hardly influenced by soil type.

Therefore, modelling concepts should consider dynamic interactions between soil water and crop growth. Crop models in general should consider recirculation of soil water and, especially in low-lying regions like deltas, groundwater dynamics should be considered as well.

Precipitation, soil texture and water table depth jointly affected the amount of groundwater recharge and time lag between water input and groundwater recharge (Ma et al., 2015). We quantified some of these issues, but several items remain, such as the impact of rooting depth on crop yield and transpiration. Also, soil and water management practises like ploughing and irrigation were not considered. Furthermore, the rooting pattern needed a more detailed analysis; we applied an exponential decrease in root density and compensation of root uptake according to Jarvis $(1989,2011)$ but the macroscopic root water uptake concept was still simple and may require a more detailed analysis (Dos Santos et al., 2017). Another item we neglected is the preferential flow of water by the occurrence of non-capillary sized macropores (Bouma, 1981; Feddes et al., 1988), which is especially relevant in clay soils. Hysteresis of the water retention function was also not considered. An additional analysis of these issues is recommended, especially the impact of different rooting patterns on capillary rise should be addressed.

The impact of soil type on yield increased when environmental conditions became dryer; situations without groundwater and without recirculation had less yield and higher yield variation than situations where groundwater influenced capillary rise (for detailed information on the results see Sects. S1 and S3).

\section{Conclusions}

We quantified the impact of upward flow on crop yields of grassland, maize and potatoes in layered soils. We compared situations with average groundwater levels with freedrainage conditions with and without upward flow. The largest impact of upward flow on crop yields was found when one compares situations with average groundwater levels with free-drainage conditions without upward flow. From these differences one may conclude that neglecting upward flow has a large impact on simulated yields and water balance calculations, especially in regions where shallow groundwater occurs. The comparison showed long-term average yield reductions for grassland, maize and potatoes of respectively 26, 3 and $14 \%$ (Table 5) or respectively 3.7, 0.3 and 1.5 t DM per hectare (Table 4). Reduction of the percolation flux can be considerable; for grassland and potatoes the reduction was 17 and $46 \%$ (Table 5) or 63 and $34 \mathrm{~mm}$ (Table 4).

About half of the yield increases was caused by internal recirculation as occurs in free-drainage conditions and the other half was caused by an increased upward capillary flow from groundwater. Improved modelling should consider upward flow of soil water which will result in improved estimates of crop yield and percolation.

We believe that the quantification of recirculation for crop yield is a novelty, especially recirculation as part of upward flow and its relation to capillary rise and crop growth. Studies about the relation between soil hydrology and crop growth should quantify this upward flow because neglecting this flow and its impact implies neglecting yield changes, which may have a large economic value in the Dutch delta and in other deltas in general. Another aspect, which could not be found in the referenced studies, is the lack of a quantification of the impact of recirculation on crop yields. Correct quantification of water fluxes contributes to the understanding of crop production and will help the institutions in charge of yield forecasting.

Data availability. The input data for the soil-crop experiments described in Sects. 2.3 and 3.2 are available at https://git.wur. nl/kroes006/Kroes_et_al_2018_HESS (last access: 10 May 2018). The source code and an executable of SWAP4.0.1 is available at http://swap.wur.nl/ (last access: 10 May 2018). An additional example, described in Sect. 4, is available as indicated in Sect. 5 of the Supplement.

\section{The Supplement related to this article is available online at https://doi.org/10.5194/hess-22-2937-2018- supplement.}

Competing interests. The authors declare that they have no conflict of interest.

Acknowledgements. Part of the case studies has been used before (Hack-ten-Broeke et al., 2016). This project is related to the project WaterVision Agriculture (www.waterwijzer.nl, last access: 7 May 2018) which is financed by a large group of financers: STOWA (Applied Research of the Water Boards), the Ministry of Infrastructure and Environment, ACSG (the Advisory Commission for Damage related to Groundwater), provinces Utrecht and Zuid-Holland, ZON (Zoetwatervoorziening Oost-Nederland), water companies Vitens and Brabant Water, VEWIN, LTO and the Ministry of Economic Affairs (project KB-14-001-046).

We also thank all reviewers for their constructive and valuable comments on earlier versions of this paper.

Edited by: Nunzio Romano

Reviewed by: Piotr Kowalik, Sally Logsdon, and two anonymous referees 


\section{References}

Ahuja, L. R., Ma, L., Lascano, R. J., Saseendran, S. A., Fang, Q. X., Nielsen, D. C., Wang, E., and Colaizzi, P. D.: Syntheses of the Current Model Applications for Managing Water and Needs for Experimental Data and Model Improvements to Enhance these Applications, in: Practical Applications of Agricultural System Models to Optimize the Use of Limited Water, Vol. 5, 399-437, 2014.

Allen, R. G., Pereira, L. S., Raes, D., and Smith, M.: FAO Irrigation and Drainage Paper No 56; Crop Evapotranspiration, FAO Irrigation and Drainage Paper, Rome, available at: http://www.fao.org/ docrep/X0490E/X0490E00.htm (last access: 7 May 2018), 1998.

Awan, U. K., Tischbein, B., and Martius, C.: A GIS-based approach for up-scaling capillary rise from field to system level under soil-crop-groundwater mix, Irrig. Sci., 32, 449-458, https://doi.org/10.1007/s00271-014-0441-5, 2014.

Babajimopoulos, C., Panoras, A., Georgoussis, H., Arampatzis, G., Hatzigiannakis, E., and Papamichail, D.: Contribution to irrigation from shallow water table under field conditions, Agr. Water Manage., 92, 205-210, 2007.

Bartholomeus, R. P., Witte, J. P. M., van Bodegom, P. M., van Dam, J. C., and Aerts, R.: Critical soil conditions for oxygen stress to plant roots: substituting the Feddes-function by a process-based model, J. Hydrol., 360, 147-165, 2008.

Bastiaanssen, W. G. M., Allen, R. G., Droogers, P., Urso, G. D., and Steduto, P.: Twenty-five years modeling irrigated and drained soils?: State of the art, Agr. Water Manage., 92, 111125, https://doi.org/10.1016/j.agwat.2007.05.013, 2007.

Bigiarini, M. Z.: Package " hydroGOF", R-package, available at: www.r-project.org/ (last access: 7 May 2018), 2013.

Bonfante, A., Basile, A., Acutis, M., De Mascellis, R., Manna, P., Perego, A., and Terribile, F.: SWAP, CropSyst and MACRO comparison in two contrasting soils cropped with maize in Northern Italy, Agr. Water Manage., 97, 1051-1062, https://doi.org/10.1016/j.agwat.2010.02.010, 2010.

Boogaard, H., Wolf, J., Supit, I., Niemeyer, S., and Ittersum, M.: A regional implementation of WOFOST for calculating yield gaps of autumn-sown wheat across the European Union, Field Crops Res., 1143, 130-142, 2013.

Bouma, J.: Soil morphology and preferential flow along macropores, Agr. Water Manage., 3, 235-250, https://doi.org/10.1016/0378-3774(81)90009-3, 1981.

De Vries, J. J.: Groundwater, in: Geology of the Netherlands, edited by: Wong, T., Batjens, D. A. J., and de Jager, J., KNAW, 295315, available at: http://www.hydrology.nl/key-publications/ 231-groundwater-geology-of-the-netherlands.html, 2007.

De Vos, J. A., Sival, F. P., Clevering, O. A., and van Kleef, J.: Stikstof- en fosfaatverliezen naar grond- en oppervlaktewater bij vernatting van landbouwgronden. Veldexperimenten Vredepeel 2003-2005, Alterra, Wageningen \& PPO-Akkerbouw, Groene Ruimte en vollegrondsgroente, Alterra-rapport 1392, Lelystad en Wageningen, 2006.

De Wit, C. T.: Photosynthesis of leaf canopies. Versl. Landbouwk. Onderz. (Agric. Res. Rep.) 663, Wageningen, available at: http: //edepot.wur.nl/187115 (last access: 7 May 2018), 1965.

De Wit, A. J. W. and van Diepen, C. A.: Crop growth modelling and crop yield forecasting using satellite-derived meteorological inputs, Int. J. Appl. Earth Observ. Geoinform., 10, 414-425, 2008.
De Wit, A. J. W., Duveiller, G., and Defourny, P.: Estimating regional winter wheat yield with WOFOST through the assimilation of green area index retrieved from MODIS observations, Agr. Forest Meteorol., 164, 39-52, 2012.

Dijkstra, J. P., Hack-ten Broeke, M. J. D., and Wijnands, F. G.: Stikstofemissie naar het grondwater van geintegreerde en gangbare bedrijfssystemen in de akkerbouw op de proefboerderijen Borgerswold en Vredepeel: simulatie van de vocht- en nitraathuishouding op de proefboerderij Vredepeel voor de jaren 1990-1993, DLO-Staring Centrum, Rapport 287.3, Wageningen, 1995.

Dos Santos, M. A., de Jong van Lier, Q., van Dam, J. C., and Freire Bezerra, A. H.: Benchmarking test of empirical root water uptake models, Hydrol. Earth Syst. Sci., 21, 473-493, https://doi.org/10.5194/hess-21-473-2017, 2017.

Eitzinger, J., Trnka, M., Hösch, J., Žalud, Z., and Dubrovský, M.: Comparison of CERES , WOFOST and SWAP models in simulating soil water content during growing season under different soil conditions, Ecol. Modell., 171, 223-246, https://doi.org/10.1016/j.ecolmodel.2003.08.012, 2004.

Elbers, J. A., Moors, E. J., and Jacobs, C. M. J.: Gemeten actuele verdamping voor twaalf locaties in Nederland. Alterrarapport 1920, available at: http://library.wur.nl/WebQuery/ wurpubs/445274 (last access: 8 May 2018), 2009.

Fan, Y., Li, H., and Miguez-Macho, G.: Global patterns of groundwater table depth, Science, 339, 940-943, https://doi.org/10.1126/science.1229881, 2013.

Feddes, R. A., Kowalik, P. J., and Zaradny, H.: Simulation of field water use and crop yield, Simul. Monogr., Pudoc, Wageningen, 189 pp., 1978.

Feddes, R. A., Kabat, P., Bakel, P. J. T. Van, Bronswijk, J., and Halbertsma, J.: Modelling soil water dynamics in the unsaturated zone - state of the art, J. Hydrol., 100, 69-111, 1988.

Feodoroff, A.: Redistribution of moisture after infiltration in dry soils, Influence of gravity, 385-389, in: Water in the unsaturated zone; L'eau dans la zone non saturée, edited by: Rijtema, P. E. and Wassink, H., Vol. I, II, 1-525 (I) and 526995 (II)), Proceedings of the Wageningen Symposium by UNESCO - IASH, available at: http://unesdoc.unesco.org/images/ 0001/000143/014319mo.pdf (last access: 7 May 2018), 1969.

Geerts, S., Raes, D., Garcia, M., Condori, O., Mamani, J., Miranda, R., Cusicanqui, J., Taboada, C, Yucra, E., and Vacher, J.: Could deficit irrigation be a sustainable practice for quinoa (Chenopodium quinoa Willd.) in the Southern Bolivian Altiplano?, Agr. Water Manage., 95, 909-917, https://doi.org/10.1016/j.agwat.2008.02.012, 2008.

Guderle, M. and Hildebrandt, A.: Using measured soil water contents to estimate evapotranspiration and root water uptake profiles - a comparative study, Hydrol. Earth Syst. Sci., 19, 409425, https://doi.org/10.5194/hess-19-409-2015, 2015.

Hack-ten Broeke, M. J. D. and Hegmans, J. H. B. M.: Use of soil physical characteristics from laboratory measurements or standard series for modelling unsaturated water flow, Agr. Water Manage., 29, 201-213, 1996.

Hack-ten-Broeke, M. J. D., Kroes, J. G., Bartholomeus, R. P., Dam, J. C. Van, Wit, A. J. W. De, Supit, I., Walvoort, D. J. J., van Bakel, P. J. T., and Ruijtenberg, R.: Quantification of the impact of hydrology on agricultural production as a result of too dry, too wet or too saline conditions, in: Soil, 2, 391-402, 2016. 
Han, M., Zhao, C., Šimůnek, J., and Feng, G.: Evaluating the impact of groundwater on cotton growth and root zone water balance using Hydrus-1D coupled with a crop growth model, Agr. Water Manage., 160, 64-75, https://doi.org/10.1016/j.agwat.2015.06.028, 2015.

Hooghoudt, S. B.: Contributions to the Knowledge of Some Physical Soil Properties, No. 43, 461-676, Determination of the Conductivity of Soils of the Second Kind, in: Dutch: Verslagen van Landbouwkundige Onderzoekingen, no. 43 B, Dep. van Economische Zaken, Directie van den Landbouw, Algemeene Landsdrukkerij, The Hague, 1937.

Huo, Z., Feng, S., Huang, G., Zheng, Y., Wang, Y., and Guo, P.: Effect of groundwater level depth and irrigation amount on water fluxes at the groundwater table and water use of wheat, Irrig. Drain., 61, 348-356, https://doi.org/10.1002/ird.685, 2012.

Jarvis, N. J.: A simple empirical model of root water uptake, J. Hydrol., 107, 57-72, 1989.

Jarvis, N. J.: Simple physics-based models of compensatory plant water uptake: concepts and eco-hydrological consequences, Hydrol. Earth Syst. Sci., 15, 3431-3446, https://doi.org/10.5194/hess-15-3431-2011, 2011.

KNMI: Royal Netherlands Meteorologica 1 Institute (KNMI), DeBilt, available at: http://www.knmi.nl/ (last access: 7 May 2018), 2016.

Kowalik, P. J.: Drainage and capillary rise components in water balance of alluvial soils, Agr. Water Manage., 86, 206-211, https://doi.org/10.1016/j.agwat.2006.08.003, 2006.

Kroes, J. G. and Supit, I.: Impact analysis of drought, water excess and salinity on grass production in The Netherlands using historical and future climate data, Agr. Ecosyst. Environ., 144, 370-381, https://doi.org/10.1016/j.agee.2011.09.008, 2011.

Kroes, J., Bartholomeus, R., van Dam, J., Hack-ten Broeke, M., Supit, I., Hendriks, R., de Wit, A., van der Bolt, F., Walvoort, D., Hoving, I., and Van Bakel, J.: Waterwijzer Landbouw, fase 2. Modellering van het bodem-water-plantsysteem met het gekoppelde instrumentarium SWAP-WOFOST (Eng: Watervision Agriculture, phase 2. Modeling of the soil-water-plant system with SWAP-WOFOST), Rapport 2015-16, STOWA, Amersfoort, available at: http://waterwijzer.stowa.nl/Upload/ publicatie2014/STOWA\%202015\%2016\%20WEB\%20LR.pdf (last access: 14 May 2018), 2015.

Kroes, J. G., Dam, J. C. van, Bartholomeus, R. P., Groenendijk, P., Heinen, M., Hendriks, R. F. A., Mulder, H.M., Supit, I., van, and Walsum, P. E. V.: SWAP version 4, Theory description and user manual, Wageningen Environmental Research, ESG Report 2780, available at: http://library.wur.nl/WebQuery/wurpubs/ fulltext/416321 (last access: 7 May 2018), 2017.

Ma, Y., Feng, S., and Song, X.: Evaluation of optimal irrigation scheduling and groundwater recharge at representative sites in the North China Plain with SWAP model and field experiments, Comput. Electro. Agr., 116, 125-136, https://doi.org/10.1016/j.compag.2015.06.015, 2015.

Norman, J. M.: Fifty Years of Study of S-P-A Systems: Past Limitations and a Future Direction, Proc. Environ. Sci., 19, 15-25, https://doi.org/10.1016/j.proenv.2013.06.003, 2013.

Oster, J. D., Letey, J., Vaughan, P., Wu, L., and Qadir, M.: Comparison of transient state models that include salinity and matric stress effects on plant yield, Agr. Water Manage., 103, 167-175, https://doi.org/10.1016/j.agwat.2011.11.011, 2012.
Rallo, G., Agnese, C., Minacapilli, M., and Provenzano, G.: Comparison of SWAP and FAO Agro-Hydrological Models to Schedule Irrigation of Wine Grapes, J. Irrig. Drain. Eng., 138, 581-591, https://doi.org/10.1061/(ASCE)IR.1943-4774.0000435, 2012.

Rijtema, P. E.: Een berekeningsmethode voor de benadering van de landbouwschade ten gevolge van grondwateronttrekking, ICW-Nota 587, Wageningen, available at: http://library.wur.nl/ WebQuery/wurpubs/advanced/422164 (last access: 7 May 2018), 1971.

Romano, N., Palladino, M., and Chirico, G. B.: Parameterization of a bucket model for soil-vegetation-atmosphere modeling under seasonal climatic regimes, Hydrol. Earth Syst. Sci., 15, $3877-$ 3893, https://doi.org/10.5194/hess-15-3877-2011, 2011.

Rötter, R.: Simulation of the biophysical limitations to maize production under rainfed conditions in Kenya, Evaluation and application of the Model WOFOST, Materiel zur Ost-Afrika vorschung, Heft 12, 261+, Annexes, 1993.

Šimůnek, J., Sejna, M., Saito, H., Sakai, M., and van Genuchten, M. T.: The HYDRUS-1D Software Package for Simulating the OneDimensional Movement of Water, Heat, and Multiple Solutes in Variably-Saturated Media, Version 4.0 April 2008, Environmental Sciences, Riverside, California, 2008.

SSSA: Glossary of Soil Science Terms 2008, Soil Science Society of America, Soil Sci., available at: https://www.soils.org/ publications/soils-glossary\# (last access: 7 May 2018), 2008.

Supit, I.: An exploratory study to improve the predictive capacity of the Crop Growth Monitoring Systems as applied by the European Commission, Doctoraal thesis, Wageningen University, Wageningen, The Netherlands, available at: http://library.wur.nl/ WebQuery/wurpubs/fulltext/196579 (last access: 7 May 2018), 2000.

Supit, I., van Diepen, C. A., de Wit, A. J. W., Wolf, J., Kabat, P., Baruth, B., and Ludwig, F.: Assessing climate change effects on European crop yields using the Crop Growth Monitoring System and a weather generator, Agr. Forest Meteorol., 164, 96-111, 2012.

Talebnejad, R. and Sepaskhah, A. R.: Effect of different saline groundwater depths and irrigation water salinities on yield and water use of quinoa in lysimeter, Agr. Water Manage., 148, 177188, https://doi.org/10.1016/j.agwat.2014.10.005, 2015.

Van Bakel, P. J. T., Massop, H. Th. L., Kroes, J. G., Hoogewoud, J., Pastoors, R., and Kroon, T.: Actualisatie Hydrologie voor STONE 2.3; Aanpassing randvoorwaarden en parameters, koppeling tussen NAGROM en SWAP, en plausibiliteitstoets, (Eng: Updating the hydrology component in STONE 2.3; Adjusting boundary conditions and parameters, linking NAGROM and SWAP, and plausibility test), WOt-rapport 57, Wettelijke Onderzoekstaken Natuur \& Milieu (MNP), Alterra, Wageningen, The Netherlands, 2008.

van Dam, J. C., Groenendijk, P., Hendriks, R. F. A., and Kroes, J. G.: Advances of Modeling Water Flow in Variably Saturated Soils with SWAP, Vadose Zone J., 7, 640-653, https://doi.org/10.2136/vzj2007.0060, 2008.

Van den Brande, M.: Remote sensing beelden van NDVI en hydrologisch modelleren, BSc thesis Wageningen UR, Wageningen, 2013.

Van der Gaast, J. W., Massop, H. T. L., and Vroon, H. R. J.: Effecten van klimaatverandering op de watervraag in de Nederlandse 
groene ruimte, Alterra-rapport 1791, Wageningen, available at: http://edepot.wur.nl/7870 (last access: 7 May 2018), 2009.

Van der Ploeg, M. J. and Teuling, A. J.: Going Back to the Roots: The Need to Link Plant Functional Biology with Vadose Zone Processes, Proc. Environ. Sci., 19, 379-383, https://doi.org/10.1016/j.proenv.2013.06.043, 2013.

Van Diepen, C. A. van, Wolf, J., and van Keulen, H.: WOFOST: a simulation model of crop production, Soil Use Manage., 5, 1624, 1989.

Van Gaelen, H., Vanuytrecht, E., Willems, P., Diels, J., and Raes, D.: Bridging rigorous assessment of water availability from field to catchment scale with a parsimonious agrohydrological model, Environ. Modell. Softw., 94, 140-156, https://doi.org/10.1016/j.envsoft.2017.02.014, 2017.

Van Ittersum, M. K., Leffelaar, P. A., van Keulen, H., Kropff, M. J., Bastiaans, L., and Goudriaan, J.: On approaches and applications of the Wageningen crop models, Eur. J. Agro., 18, 201-234, 2003.

Van Keulen, H. and Wolf, J. (Eds): Modelling of agricultural production: weather, soils and crops, Simulation Monographs, $\mathrm{Pu}-$ doc Wageningen, The Netherlands, 1986.

Verloop, J., Hilhorst, G. J., Oenema, J., Van Keulen, H., Sebek, L. B. J., and Van Ittersum, M. K.: Soil N mineralization in a dairy production system with grass and forage crops, Nut. Cy. Agroecosyst., 98, 267-280, https://doi.org/10.1007/s10705-014-96104, 2014.

Videla Mensegue, H., Degioanni, A., and Cisneros, J.: Estimating shallow water table contribution to soybean water use in Argentina, Eur. Sci. J., 11, 23-40, 2015.
Wesseling, J. G.: CAPSEV: steady state moisture flow theory. Program description, user manual. Wageningen, Staring Centre. Report 37, available at: http://edepot.wur.nl/360382 (last access: 7 May 2018), 1991.

Wesseling, J. G. and Feddes, R. A.: Assessing crop water productivity from field to regional scale, Agr. Water Manage., 86, 30-39, https://doi.org/10.1016/j.agwat.2006.06.011, 2006.

Wösten, H., de Vries, F., Hoogland, T., Massop, H., Veldhuizen, A., Vroon, H., Wesseling, J, Heijkers, J., and Bolman, A.: BOFEK2012, the new soil physical schematisation of The Netherlands, (in Dutch: BOFEK2012, de nieuwe, bodemfysische schematisatie van Nederland); Alterra-rapport 2387, Wageningen, 2013a.

Wösten, J. H. M., Verzandvoort, S. J. E., Leenaars, J. G. B., Hoogland, T., and Wesseling, J. G.: Soil hydraulic information for river basin studies in semi-arid regions, Geoderma, 195-196, 79-86, https://doi.org/10.1016/j.geoderma.2012.11.021, 2013b.

Wu, Y., Liu, T., Paredes, P., Duan, L., and Pereira, L. S.: Water use by a groundwater dependent maize in a semiarid region of Inner Mongolia: Evapotranspiration partitioning and capillary rise, Agr. Water Manage., 152, 222-232, https://doi.org/10.1016/j.agwat.2015.01.016, 2015.

Xu, X., Huang, G., Sun, C., Pereira, L. S., Ramos, T. B., Huang, Q., and Hao, Y.: Assessing the effects of water table depth on water use, soil salinity and wheat yield: Searching for a target depth for irrigated areas in the upper Yellow River basin, Agr. Water Manage., 125, 46-60, https://doi.org/10.1016/j.agwat.2013.04.004, 2013.

Zipper, S. C., Soylu, M. E., Booth, E. G., and Loheide, S. P.: Untangling the Effect of Shallow Groundwater and Soil Texture as Drivers of Subfield-Scale Yield Variability, Water Resour. Res., 51, 1-21, https://doi.org/10.1002/2015WR017522, 2015. 